Article

\title{
Identification and Characterizations of Novel, Selective Histone Methyltransferase SET7 Inhibitors by Scaffold Hopping- and 2D-Molecular Fingerprint-Based Similarity Search
}

\author{
Hong Ding ${ }^{1,2} \mathbb{1}^{\mathbb{B}}$, Wen Chao Lu ${ }^{2}{ }^{(0)}$, Jun Chi Hu ${ }^{2}$, Yu-Chih Liu ${ }^{3}$, Chen Hua Zhang ${ }^{3}$,

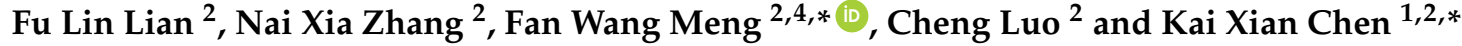 \\ 1 School of Pharmacy, Shanghai University of Traditional Chinese Medicine, 1200 Cailun Road, \\ Shanghai 201203, China; hding@simm.ac.cn \\ 2 CAS Key Laboratory of Receptor Research, State Key Laboratory of Drug Research, \\ Shanghai Institute of Materia Medica, Chinese Academy of Sciences, 555 Zuchongzhi Road, \\ Shanghai 201203, China; wenchaolu@simm.ac.cn (W.C.L.); hujunchi@simm.ac.cn (J.C.H.); \\ fulinlian1986@simm.ac.cn (F.L.L.); nxzhang@simm.ac.cn (N.X.Z.); e-cluo@simm.ac.cn (C.L.) \\ 3 Shanghai ChemPartner Co., Ltd., \#5 Building, 998 Halei Road, Shanghai 201203, China; \\ yzhliu@chempartner.com (Y.-C.L.); chhzhang@chempartner.com (C.H.Z.) \\ 4 Department of Chemistry and Chemical Biology, McMaster University, 1280 Main Street West, Hamilton, \\ ON L8S 4L8, Canada \\ * Correspondence: mengf9@mcmaster.ca (F.W.M.); kxchen@simm.ac.cn (K.X.C.); \\ Tel.: +1-(905)-525-9140 (F.W.M.); +86-021-5080-6600 (K.X.C.)
}

Received: 9 February 2018; Accepted: 28 February 2018; Published: 2 March 2018

\begin{abstract}
SET7, serving as the only histone methyltransferase that monomethylates 'Lys-4' of histone $\mathrm{H} 3$, has been proved to function as a key regulator in diverse biological processes, such as cell proliferation, transcriptional network regulation in embryonic stem cell, cell cycle control, protein stability, heart morphogenesis and development. What's more, SET7 is involved inthe pathogenesis of alopecia aerate, breast cancer, tumor and cancer progression, atherosclerosis in human carotid plaques, chronic renal diseases, diabetes, obesity, ovarian cancer, prostate cancer, hepatocellular carcinoma, and pulmonary fibrosis. Therefore, there is urgent need to develop novel SET7 inhibitors. In this paper, based on DC-S239 which has been previously reported in our group, we employed scaffold hopping- and 2D fingerprint-based similarity searches and identified DC-S285 as the new hit compound targeting SET7 $\left(\mathrm{IC}_{50}=9.3 \mu \mathrm{M}\right)$. Both radioactive tracing and NMR experiments validated the interactions between DC-S285 and SET7 followed by the second-round similarity search leading to the identification ofDC-S303 with the $\mathrm{IC}_{50}$ value of $1.1 \mu \mathrm{M}$. In cellular level, DC-S285 retarded tumor cell proliferation and showed selectivity against MCF7 $\left(\mathrm{IC}_{50}=21.4 \mu \mathrm{M}\right)$, Jurkat $\left(\mathrm{IC}_{50}=2.2 \mu \mathrm{M}\right)$, THP1 $\left(\mathrm{IC}_{50}=3.5 \mu \mathrm{M}\right), \mathrm{U} 937\left(\mathrm{IC}_{50}=3.9 \mu \mathrm{M}\right)$ cell lines. Docking calculations suggested that DC-S303 share similar binding mode with the parent compoundDC-S239. What's more, it presented good selectivity against other epigenetic targets, including SETD1B, SETD8, G9a, SMYD2 and EZH2. DC-S303 can serve as a drug-like scaffold which may need further optimization for drug development, and can be used as chemical probe to help the community to better understand the SET7 biology.
\end{abstract}

Keywords: SET7; inhibitor; similarity search; ligand-based drug design; chemical biology probe

\section{Introduction}

In the epigenetic landscape, histone methyltransferases (HMTs) play an essential role in various biological processes including cell cycle progression [1], cell differentiation [2], development [3] as well 
as other biological processes [4]. Besides, HMTs are involved with the pathogenesis of cancers [5-8], immune-mediated diseases [9], thus they have been the hot targets for cancer therapy in both academia and industry. HMTs can be categorized into two groups based on structural features: (i) SET domain-containing subfamily, such as SET7 (SET domain-containing lysine methyltransferase 7, also called SETD7, SET9, KMT7), EZH2 (Enhancer of Zest Homologue 2) and SUV39H1 and (ii) non-SET domain containing subfamily, such as DOT1-L (Disruptor of Telomeric silencing 1-Like) [10].

SET7 is the only epigenetic member that specifically monomethylates 'Lys-4' of histone H3 and emerging evidences have proved SET7's unique role in transcriptional regulations [11] (Table 1), DNA repair [12], cell cycle control [12-14]. Due to its catalytic activity on diverse non-histone substrates, SET7 also displays a special role in a lot of biological processes (Table 1) and is involved in cell proliferation [15,16], transcriptional network regulation in embryonic stem cell $[17,18]$, cell cycle control [19], protein stability [20-23], heart morphogenesis and development [24], as well as other biological functions. Notably, its role in regulating p53, whose mutant isoform is an important cancer therapy target [25], remains controversial [26].

Table 1. SET7 substrates and its biological functions.

\begin{tabular}{|c|c|c|c|}
\hline \multicolumn{2}{|c|}{ Substrates } & \multirow{2}{*}{$\frac{\text { Functions }}{\text { transcriptional activation }}$} & \multirow{2}{*}{$\frac{\text { References }}{[27,28]}$} \\
\hline Histone & H3К 4 & & \\
\hline & $\mathrm{H} 2 \mathrm{~A}$ & & [29] \\
\hline & H2BK15 & & [29] \\
\hline & H1.4 & & [30] \\
\hline \multirow[t]{43}{*}{ Non-histone } & ARTD1 & stimulating poly-ADP-ribose formation after oxidative stress & [31] \\
\hline & COL2A1 & morphology-dependent COL2A1 gene transactivation & {$[32]$} \\
\hline & DNMT1 & protein stability regulation of DNMT1 (destabilization) & {$[33,34]$} \\
\hline & E2F1 & regulation of E2F1 stabilization co-activator in response to DNA damage & {$[35,36]$} \\
\hline & $\mathrm{ER} \alpha$ & protein stability regulation of $\mathrm{ER} \alpha$ (stabilization) and enhancing transcriptional activity & {$[20,37]$} \\
\hline & FoxO3 & protein stability regulation of FoxO3 (destabilization) & {$[38]$} \\
\hline & FXR & transcriptional activation of FXR-target genes & [39] \\
\hline & GATA1 & required for GATA1-induced breast tumour angiogenesis and growth in nude mice; poor & [40] \\
\hline & Gli3 & activation of Sonic Hedgehog pathway in mammals & [41] \\
\hline & HIF-1 $\alpha$ & $\begin{array}{l}\text { promoting HIF-1 } \alpha \text { protein stability in hypoxia and enhancing HIF-1 mediated glycolytic } \\
\text { gene transcription }\end{array}$ & {$[21]$} \\
\hline & HIF- $1 \alpha / 2 \alpha$ & $\begin{array}{c}\text { negatively regulation HIF- } \alpha \text { transcriptional activity and HIF-1-mediated } \\
\text { glucose homeostasis }\end{array}$ & {$[42,43]$} \\
\hline & IFITM3 & negatively affected IFITM3 antiviral activity & [44] \\
\hline & MCP-1 & regulation of MCP-1 mRNA expression & [45] \\
\hline & MYPT1 & protein stability regulation of MYPT1 (stabilization) & [23] \\
\hline & $\mathrm{p} 21$ & & [46] \\
\hline & p53 & & \\
\hline & p65 (RelA) & regulation of NF- $\kappa B$ activity & {$[11,47,48]$} \\
\hline & PCAF & & [49] \\
\hline & PDX1 & $\begin{array}{c}\text { maintenance of Pdx1 activity and } \beta \text { cell function; control insulin gene expression based on } \\
\text { glucose concentration }\end{array}$ & [50-52] \\
\hline & PCG-1 $\alpha$ & & [53] \\
\hline & $\mathrm{pRb}$ & cell cycle arrest & {$[13,14]$} \\
\hline & $\operatorname{RAR} \alpha$ & & {$[54]$} \\
\hline & $\mathrm{RB}$ & promotes cell cycle progression & [55] \\
\hline & NFE2L2 & negatively regulates the expression of NFE2L2 and its downstream genes & {$[56]$} \\
\hline & Smad7 & & {$[57,58]$} \\
\hline & SIRT1 & inducing the dissociation of SIRT1 from p 53 and increasing p 52 activity & [59] \\
\hline & STAT3 & negatively regulation of protein stability and transactivation activity & {$[22]$} \\
\hline & SUV39H1 & gene instability and cell proliferation inhibition & {$[12,60]$} \\
\hline & TAF7 & RNA polymerase ii-dependent transcription coactivator & [61] \\
\hline & TAF10 & RNA polymerase ii-dependent transcription coactivator & [62] \\
\hline & TAT & enhancing HIV transcription & {$[63]$} \\
\hline & TGF- $\beta 1$ & transcriptional activation of fibrotic genes & {$[64,65]$} \\
\hline & TP2 & elongating to condensing spermatids & [66] \\
\hline & YAP & control YAP subcellular localization and function & {$[67]$} \\
\hline & YY1 & regulation of YY1 DNA-binding activity & [68] \\
\hline & AKA6 & unknown & [29] \\
\hline & CENPC & unknown & [29] \\
\hline & $\mathrm{MeCP} 2$ & unknown & [29] \\
\hline & MINT & unknown & [29] \\
\hline & PPARBP, & unknown & [29] \\
\hline & ZDH8 & unknown & [29] \\
\hline & Cullin1 & unknown & [29] \\
\hline & IRF1/2 & unknown & [29] \\
\hline
\end{tabular}


In addition, SET7 is reported to be a key regulator in the pathogenies of several diseases in cluding alopecia areata [69], breast cancer [37,70], tumour and cancer progression [71-76], atherosclerosis in human carotid plaques [77], chronic renal diseases, diabetes [45,78-84], obesity [85], ovarian cancer [86], prostate cancer [87], hepatocellular carcinoma [71], and pulmonary fibrosis [57]. Of interest, the role of SET7 in viral infection is being uncovered. Studies revealed that SET7 can facilitate HCV replication in an enzymatic activity-dependent manner through attenuation of the IFN/JAK/STAT pathway [88]. SET7 binds with HIV-1 TAR RNA and monomethylates the HIV viral trans-activator Tat protein at Lys-51 and Lys-71, to enhance HIV transcription [63,89]. Knockdown analysis also proved that SET7 only suppresses Tat transactivation of the viral promoter and has on influence on transcriptional activity of methylation-deficient Tat Shan's study suggested that SET7 can negatively regulate the anti-viral activity toward vesicular stomatitis virus (VSV) and influenza A by methylation at Lys-88 of virus (IAV) infection of Interferon-induced Transmembrane Protein 3 (IFITM3) [44]. What's more, SET7 may also have a potential role in HPV (human papillomaviruses) viral survival [90]. Therefore, SET7 may be a promising target for viral infection and potent and selective inhibitor can serve as a useful chemical biology tool to elucidate the viral infection mechanism. The abberant expression patterns and dysfunction of SET7 has also been widely observed in the onset and progression of cancers. In peripheral blood mononuclear cells of patients, the histone modification patterns were greatly altered and the expression of SET7 was elevated [69]. Emerging evidence has also demonstrated its role in solid tumors. Zhang et al. demonstrated that SET7 interacts with transcription factor GATA1 and promotes downstream VEGF transcription and tumor angiogenesis [40]. Inhibition of SET7 activity by the SET7 inhibitor cyproheptadine reduced the estrogen receptor alpha expression in MCF7 cells that is important for cancer progression, phencopying the SET7 knockdown studies [37]. With SET7's emerging role of therapy targets for cancers, diabetes, hepatocellular carcinoma, alopecia areata, pulmonary fibrosis and viral infections, a potent and selective SET7 inhibitor is in great need to serve as a chemical probe to investigate its delicate biological function and mechanism.

So far, several successful attempts have been made to develop SET7 inhibitors. (R)-PFI-2 [91], as resolved in the crystal complex structure, is bound to the peptide binding pocket with a high affinity $\left(\mathrm{IC}_{50}=2.0 \mathrm{nM}\right)$. Using a drug repositioning strategy, Cyproheptadine, a clinically approved antiallergy drug was reported to bind with SET7 peptide binding site as revealed in structural biology studies $\left(\mathrm{IC}_{50}=1.0 \mu \mathrm{M}\right)[61]$.

Computational tools and methods have been widely used for epigenetic inhibitor design and discovery and many successful cases have been reported [92]. Some epigenetic inhibitors have been identified by computational methods targeting PRMT1, DNMT1, DOTL and the protein-protein interfaces like menin-mixed lineage leukemia 1 and EZH2-EED [92]. In our previous study, two selective SET7 inhibitors DC-238 and DC-S239 were identified with an integrated virtual screening method combing pharmacophore and docking as well as chemical modifications [92].

In this paper, a new SET7 inhibitor DC-S285 was identified by scaffold hopping and 2D fingerprint -based similarity search based on the previously identified SET7 inhibitor DC-S239, which was further validated by radioactivity assay and NMR-spectroscopy methods. In cellular level, DC-S285 also inhibited cancer cell proliferation in leukemic cells and breast cancer cells. Therefore, a similarity search was performed in search of more potent inhibitors as well as for its structure-activity relationship (SAR) studies. The predicted binding mode was also investigated in accordance with its SAR. In summary, a novel and selective compound DC-S336 $\left(\mathrm{IC}_{50}=1.1 \mu \mathrm{M}\right)$ was identified by similarity based search.

\section{Results and Discussions}

\subsection{Scaffold Hopping- and Similarity-Based Virtual Screening}

Based on our previous research, two selective SET7 inhibitors, namely DC-S238 (IC50 = $4.9 \mu \mathrm{M})$ and DC-S239 $(\mathrm{IC} 50=4.6 \mu \mathrm{M})$ were obtained (Figure 1A). Herein, with DC-S239 serving as the starting point, combinatorial scaffold hopping [93] and 2D fingerprint based similarity search strategies were 
employed in order to discover more SET7 inhibitors with novel chemotypes (Figure 2). The overall computational pipeline has been demonstrated (Figure 1C).
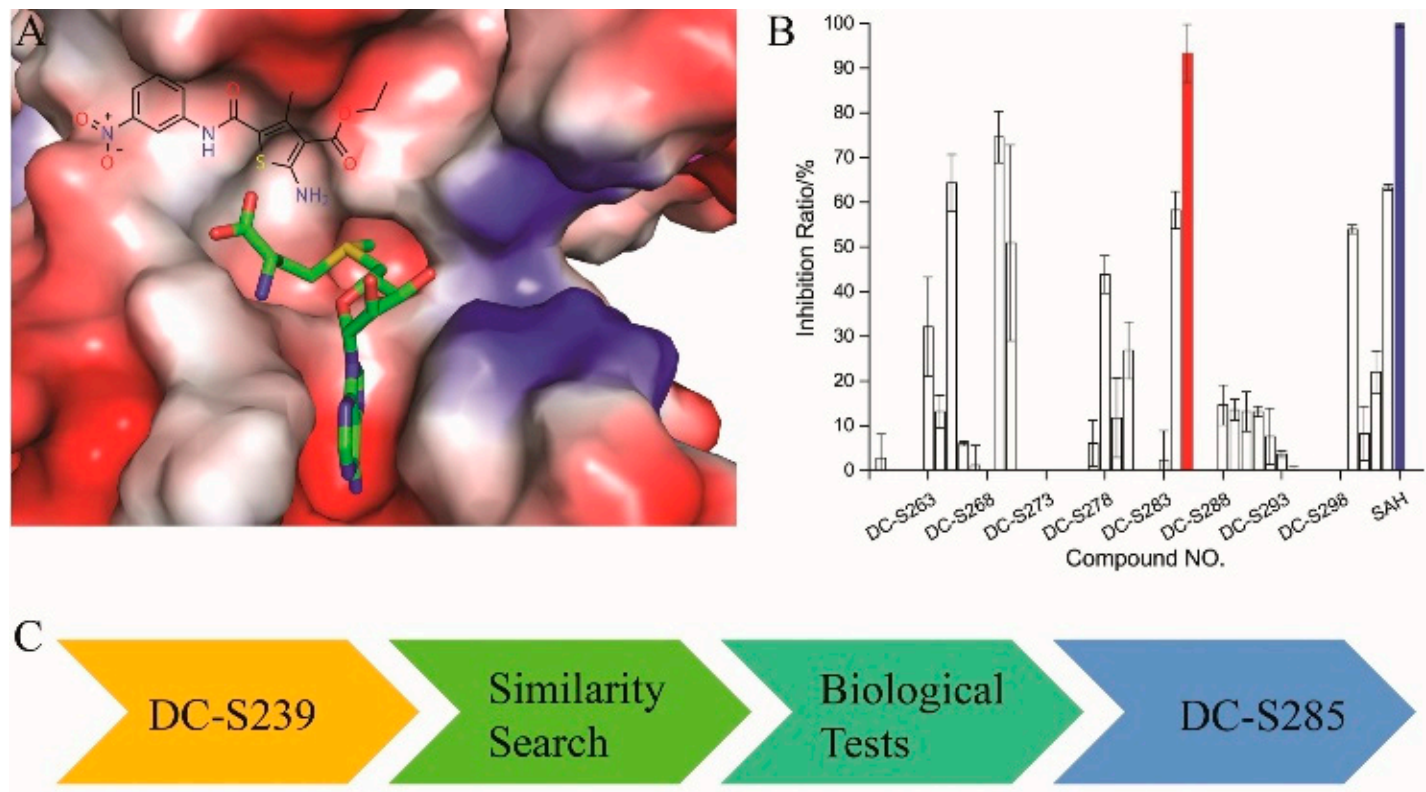

Figure 1. The flowchart of the combinatorial scaffold hopping and 2D fingerprint based similarity search strategies. (A) Chemical structure of DC-S239 and its predicted binding mode. DC-S239 is shown in sticks and the SET7 protein is shown in electrostatics surface; (B) Inhibition ratio of the compounds in first-round similarity search. DC-S285 is shown in red while the reference compound $\mathrm{SAH}$ is depicted in blue; (C) Workflow chart in the study.<smiles>[2H]OC(=O)c1c(N)sc(C(=O)Nc2cccc([N+](=O)[O-])c2)c1C</smiles>

DC-S238<smiles>CCOC(=O)c1c(N)sc(C(=O)Nc2cccc([N+](=O)[O-])c2)c1C</smiles>

DC-S239<smiles>COc1ccc(C(=O)N/N=C/c2ccc([N+](=O)[O-])cc2)cc1Br</smiles>

DC-S285

Figure 2. Chemical structures of DC-S238, DC-S239 and DC-S285.

Before performing similarity searches, pre-processing of the Specs molecular database was conducted with Pipeline Pilot, version 7.5 (Pipeline Pilot; Accelrys Software Inc., San Diego, CA, USA). Because a lot of clinical trial failures and unnecessary attritions were due to poor oral bioavailability [94,95], it becomes crucial to estimate druglikeness properties at the early drug design and development stage, and therefore the Specss database was filtered by Rule of Five [96]. Recently, a series of promiscuous, assay-duping molecules, namely 'pan-assay interference compounds' (PAINS), were reported due to metal chelation, chemical aggregation, redox activity, compound fluorescence, cysteine oxidation or promiscuous binding against the targets, suggesting that we should get rid of those structures in early state [97-100]. Therefore, the Specs database was further processed with the PAINS substructure filter developed in our lab using Pipeline Pilot, version 7.5. Then the remaining 182,014 molecules were subjected to moleculardocking to remove low binding affinity compounds or non-binders usingGilde docking software [101] integrated in Maestro 9.0 (Maestro, version 9.0, Schrödinger, LLC, New York, NY, USA, 2009) inXP mode [102] consideringits highest enrichment factor [103] based on our previous tests [92]. Subsequently, top ranking 2000 molecules, with all the previously tested compounds in our previous paper [92] excluded, was subjected to ChemMapper and 
2D similarity search. Then 300 compounds of each method were selected, and a total of 520 compounds were obtained after removing the duplicates. In order to cover chemical space with more diverse scaffolds, all the molecules were clustered into 30 groups and finally 44 compounds were selected and purchased from Specs Company (Quezon, Philippines) for biological tests. All the selections were based on the following criteria: (1) In order to get more confident results and more space for future optimization, molecules with simpler structure were chosen; (2) One compound is selected at least in each cluster to get more diverse chemical space; (3) All the molecules with potential reactive functional groups were not our preferences; (4) Molecules with similar structure or dramatic structural differences with DC-S239 were both considered based on our chemical intuitions.

\subsection{AlphaLISA-Based Biological Tests}

All the 44 candidate compounds cherry-picked from similarity search were evaluated for their biochemical activity against SET7 in vitro based on the AlphaLISA assay. SAH was used as the reference compound (Figure 2B). Among them, eight compounds came out at top against SET7 activity with inhibition rate $>50 \%$ at $100 \mu \mathrm{M}$ (Figure $1 \mathrm{~B}$ ), resulting in a hit rate of $18 \%$. Notably, compound DC-S285 presented similar potency as the reference compound SAH at the concentration of $100 \mu \mathrm{M}$. Then we measured the inhibitory activity at a range of concentrations for DC-S285. Based from dose-response curve, DC-S285 displayed moderate inhibitory activity against SET7 with an $\mathrm{IC}_{50}$ value of $9.3 \mu \mathrm{M}$ while the $\mathrm{IC}_{50}$ value of the reference compound SAH was about $3.2 \mu \mathrm{M}$ (Figure $3 \mathrm{~A}, \mathrm{~B}$ ).
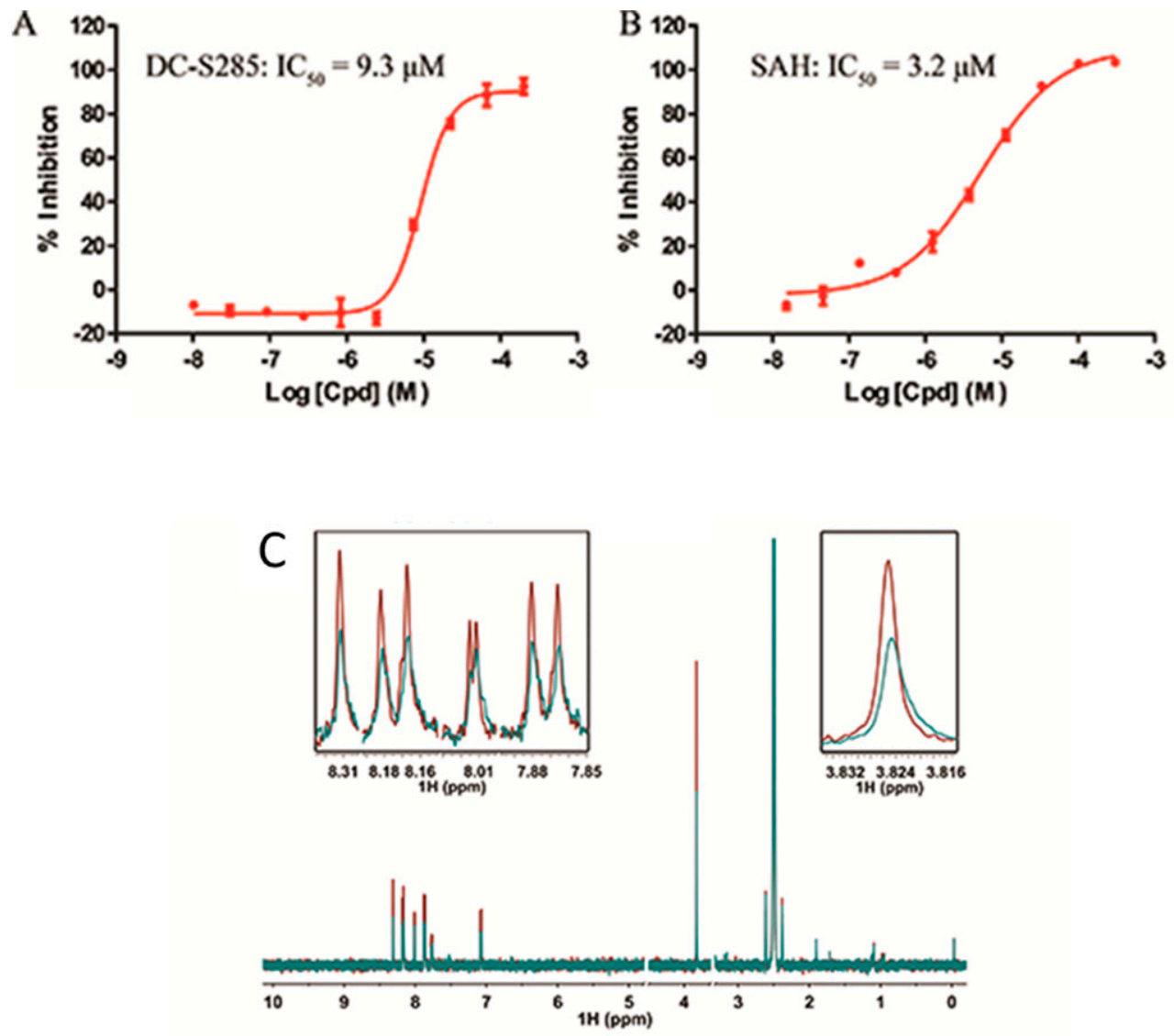

Figure 3. Activity of DC-S285 and of ligand observed 1D NMR experiments. (A,B). Inhibitory activities of DC-S285 and its reference compound SAH based on the AlphaLISA assay; (C). Carr-Purcell Meiboom-Gill Pulse Sequence reveals that DC-S285 binds to SET7. T1 $\varrho$ spectra acquired by using DC-S285 (colored in red), $20 \mu \mathrm{M}$ DC-S285 in the presence of $2.5 \mu \mathrm{M}$ protein (coloured in blue). 


\subsection{Validation of DC-S285's Activity}

To rule out the possibility of assay interference of DC-S285, we established the ${ }^{3} \mathrm{H}$-labeled radioisotope methylation assay. The $\mathrm{z}^{\prime}$ factor value of the established platform is 0.84 , demonstrating its robustness for hit validation. DC-S285 and the reference compounds SAH presented the inhibitory activity with the $\mathrm{IC}_{50}$ values of $19.5 \mu \mathrm{M}$ and $5.4 \mu \mathrm{M}$, respectively, which was in accordance with the AlphaLisa results.

In order to further confirm that compound DC-S285 binds with SET7, Carr-Purcell-Meiboom-Gill sequence (CPMG) experiments were performed for hit validation Strong binding signals were clearly observed in T1 $\varrho$ (Figure 3C) and the result indicatedthe mutually exclusive binding of DC-S285 and SET7 catalytic domain.

\subsection{Cellular Activity of DC-S285}

Collectively, both the radioactive and CPMG NMR demonstrated the direct binding between DC-S285 and SET7, wefurther evaluated its antiproliferation activities in several cancer cell lines. As depicted in Figure 4, DC-S285 significantly retard cell proliferation includingMCF7 (breast cancer), and Jurkat, THP1 and U937 leukemia cell lines in a dose-dependent manner at micromolar potencies (Figure 4).
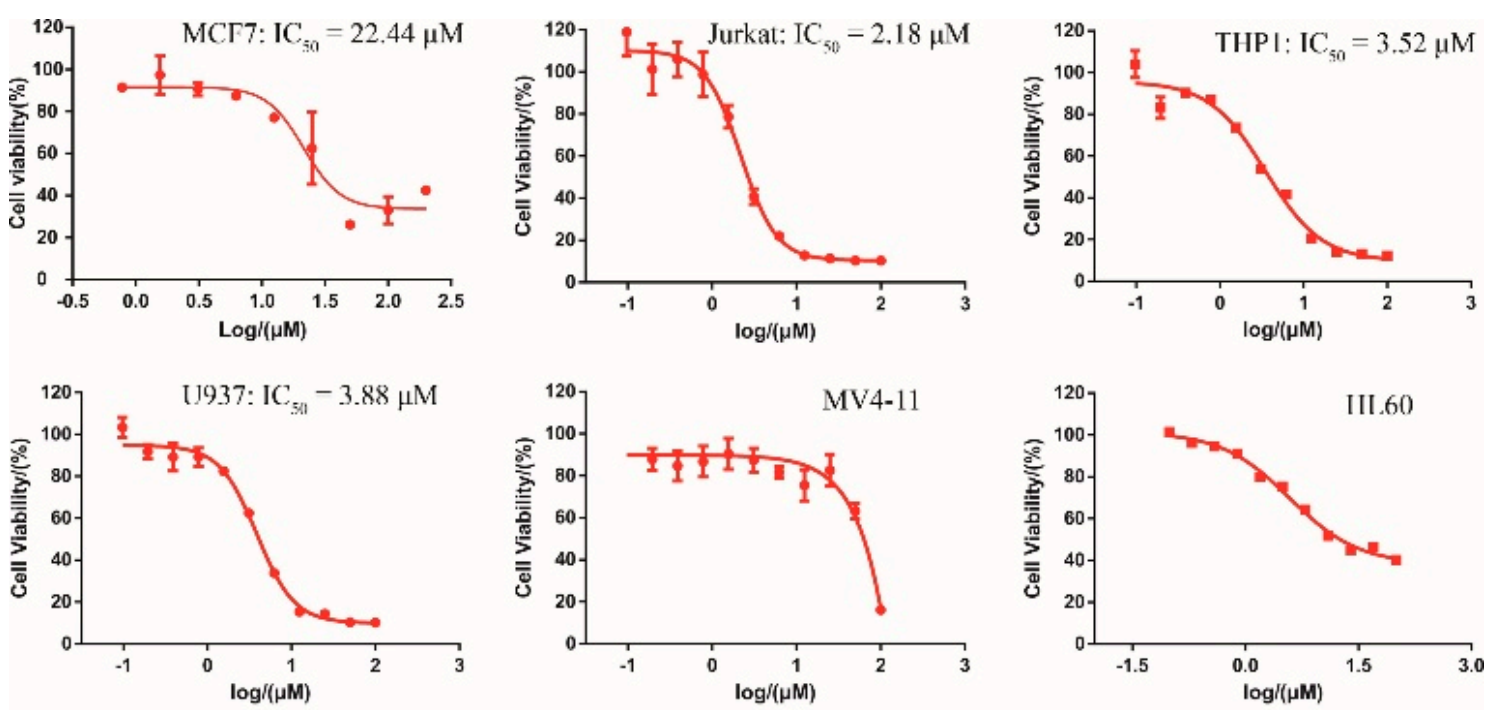

Figure 4. Cellular activity of DC-S285 against different cell lines.

\subsection{Similarity-Based Analog Searching and SAR Analysis}

Based on the biological test, the hit, DC-S285, was used as the promising scaffold for the further structure-activity relationship study (SAR). A second round 2D molecular fingerprint based similarity search was conducted using Pipeline Pilot, version 7.5 to explore the SAR and more potent inhibitors.

Some functional groups of DC-S285 were removed intentionally for similarity search, making it possible to explore the structure-activity relationship (SAR) of compound DC-S285 and for further chemical modifications. All the molecules were selected based on cluster analysis and selection criteria described before. The biological activity was measured with AlphaLISA assay at $100 \mu \mathrm{M}$ and the $\mathrm{IC}_{50}$ values of the 10 compounds with inhibition rate over $50 \%$ were determined, among which DC-S303 was the most potent SET7 inhibitor with the $\mathrm{IC}_{50}$ value of $1.1 \mu \mathrm{M}$ (Figure 5). 

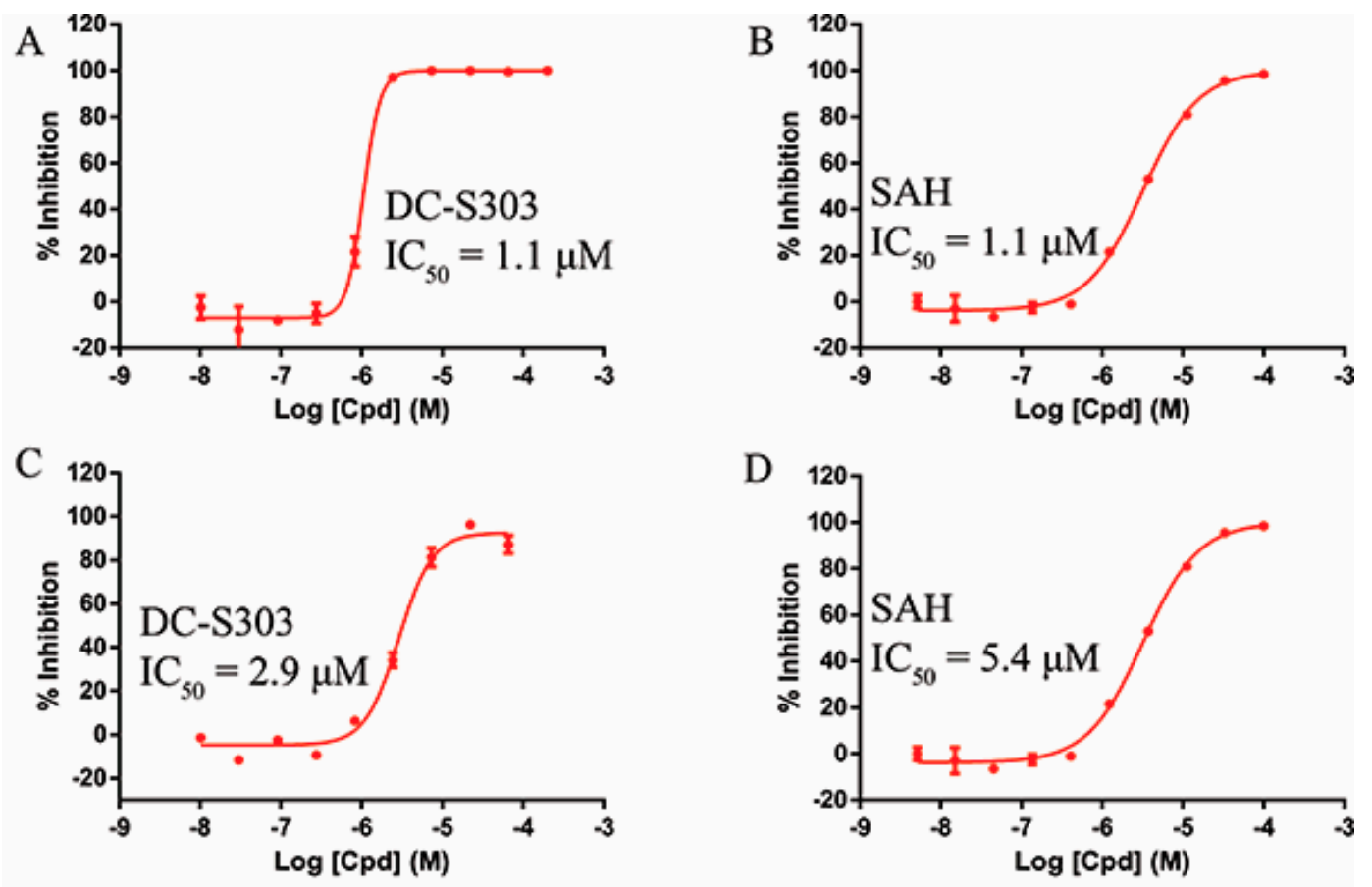

Figure 5. Enzymatic activity of DC-S303 against SET7. (A) IC 50 value of DC-S303 in AlphaLisa assay; (B) $\mathrm{IC}_{50}$ value of the reference compound $\mathrm{SAH}$ in AlphaLisa assay; (C) $\mathrm{IC}_{50}$ value of DC-S303 in radioactive assay; (D) $\mathrm{IC}_{50}$ value of the reference compound $\mathrm{SAH}$ in radioactive assay.

The SAR was summarized in Table 2. It can be concluded that the nitro group in R1 part is essential for activity comparing all the compounds from DC-S303 to DC-S313. If the nitro group is replaced by a chlorine atom, the activity decreases dramatically. What's more, the meta substituent of the nitro group is more favorable (DC-S303 and DC-S304) while DC-S305 displays no activity against SET7. DC-S301 presented moderate inhibitory activity with $\mathrm{IC}_{50}$ value of $13 \mu \mathrm{M}$, indicating the possibility that the benzene ring can be substituted by other aromatic ring with similar size. With the nitro group substituted at the meta position and chlorine atom at the ortho position, the comparison of compounds DC-S315, DC-S317, DC-S318, DC-S324, DC-S327 indicates that if the aromatic ring is not directly linked with R2 part or there is no aromatic ring linked with R2 part, the activities against SET7 decrease. DC-S314 is an exception possibly because of the flexible alkane chain meaning that it can adapt a suitable conformation to bind with SET7. Moreover, a single aromatic ring with a proper substituent will contribute to better activity. For example, if R3 is the benzene ring or a bromine substituted one, the activity is much higher than other ones (DC-S328 and DC-S333). The furan ring can contribute as an aromatic ring, but less favorable than benzene ring (DC-S329 with $\mathrm{IC}_{50}$ value $=92 \mu \mathrm{M}$ ). And it can be concluded that the diphenyl ring is the best candidate for R3 based on compound DC-S303. When R2 and R3 are fixed (from DC-S365 to DC-S364), nitro group at para position with a different R2 group from previous discussions contribute to better activity like DC-S334, but not for other substitution groups in benzene ring or aryl linkers. The rest of this table supports that the linker $A$ is the best suitable choice. 
Table 2. Structure-Activity Relationship (SAR) of DC-S303 and its derivatives.

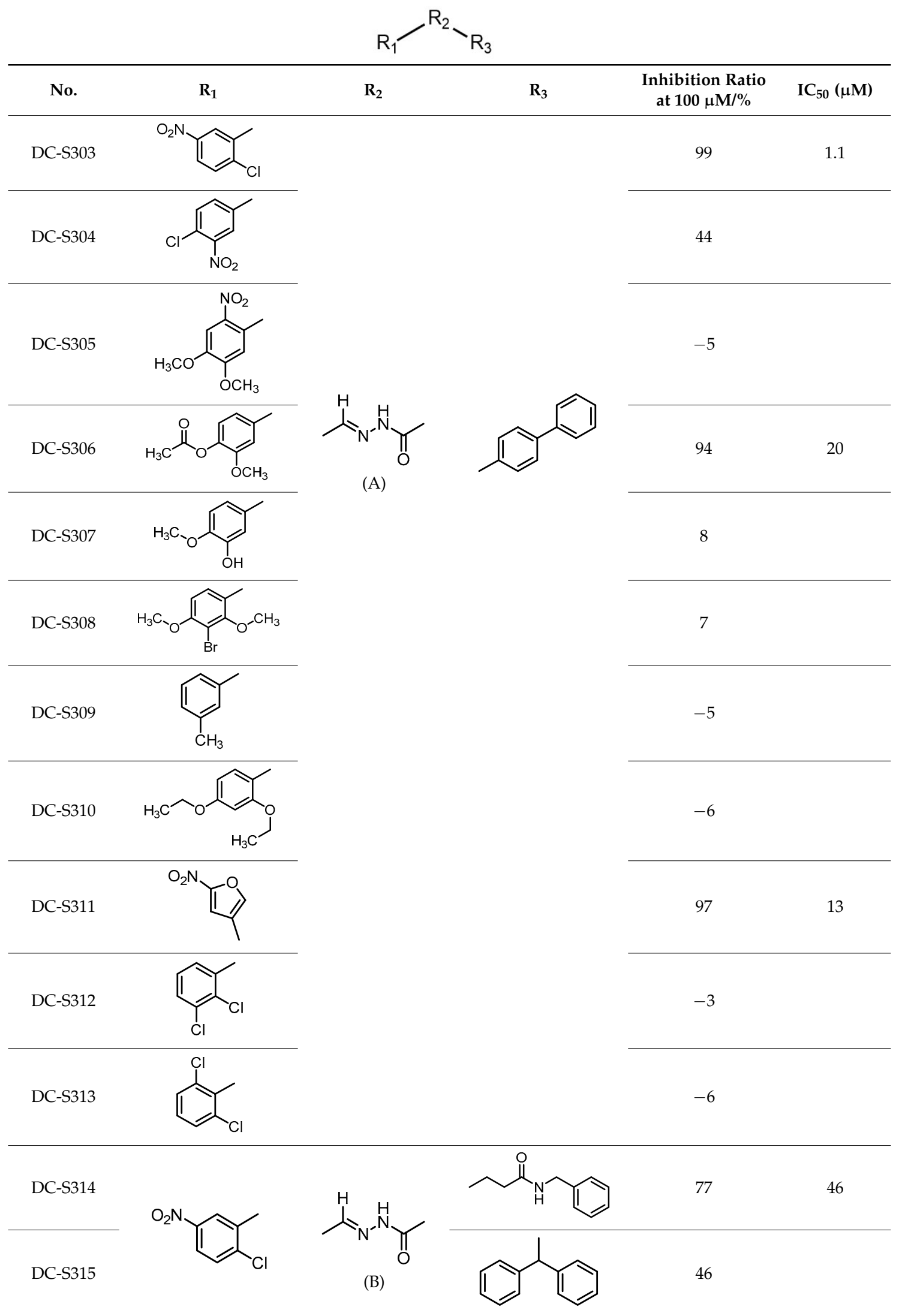


Table 2. Cont.

\begin{tabular}{|c|c|c|c|c|c|}
\hline No. & $\mathbf{R}_{1}$ & $\mathbf{R}_{2}$ & $\mathbf{R}_{3}$ & $\begin{array}{c}\text { Inhibition Ratio } \\
\text { at } 100 \mu \mathrm{M} / \%\end{array}$ & $\mathrm{IC}_{50}(\mu \mathrm{M})$ \\
\hline DC-S316 & & & & 37 & \\
\hline DC-S317 & & & & 29 & \\
\hline DC-S318 & & & & 17 & \\
\hline DC-S319 & & & & 14 & \\
\hline DC-S320 & & & & 11 & \\
\hline DC-S321 & & & & 9 & \\
\hline DC-S334 & & & & 96 & 9.9 \\
\hline DC-S335 & & (C) & & 12 & $\mathrm{IC}_{50}(\mu \mathrm{M})$ \\
\hline DC-S336 & & & & 49 & 1.1 \\
\hline DC-S337 & & & & 1 & \\
\hline DC-S338 & & & & 1 & \\
\hline DC-S339 & & & & -6 & 20 \\
\hline DC-S340 & & & & -6 & \\
\hline DC-S341 & & & & -10 & \\
\hline DC-S342 & & & & -13 & \\
\hline
\end{tabular}


Table 2. Cont.

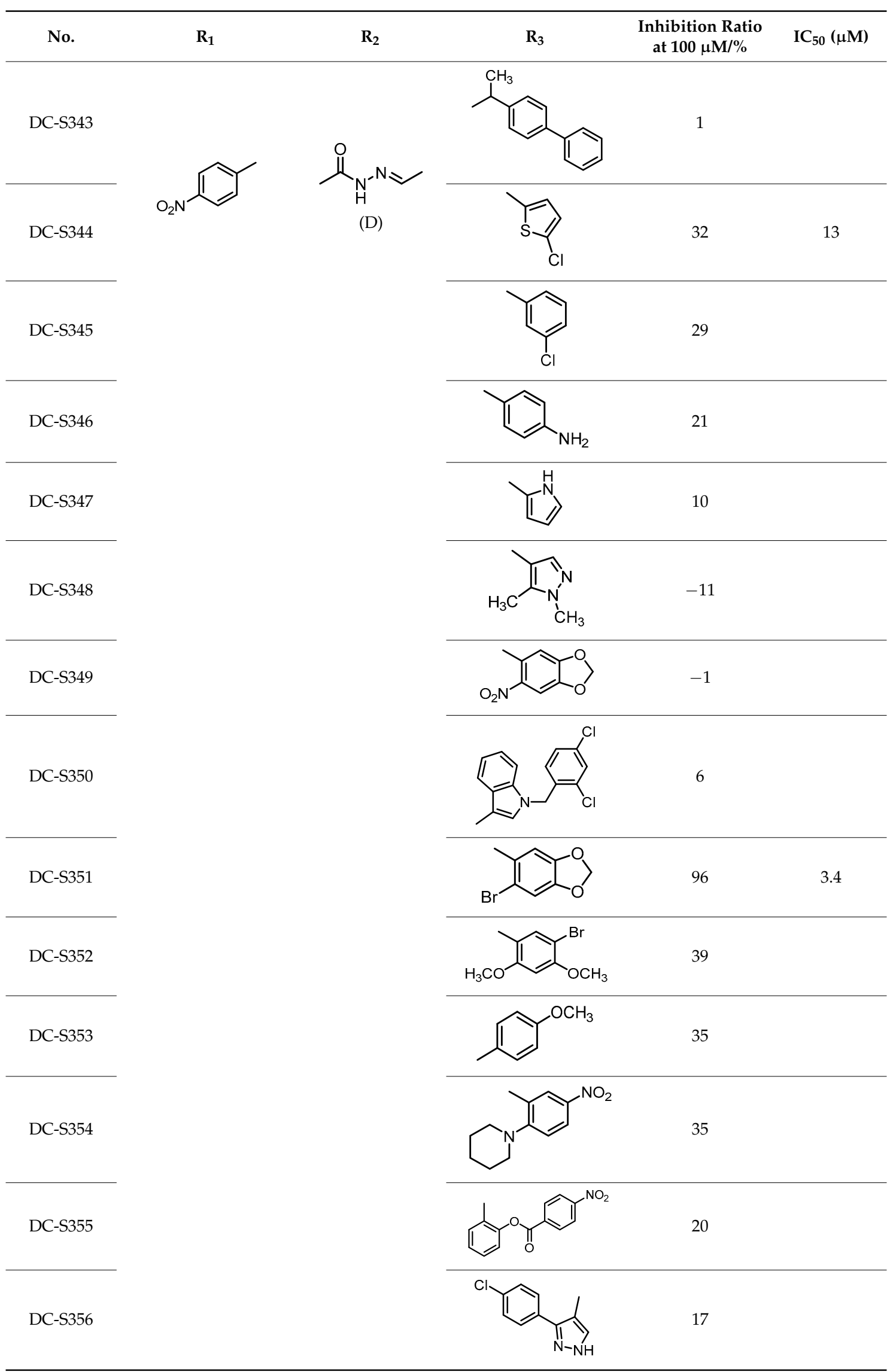


Table 2. Cont.

\begin{tabular}{|c|c|c|c|c|c|}
\hline No. & $\mathbf{R}_{1}$ & $\mathbf{R}_{2}$ & $\mathbf{R}_{3}$ & $\begin{array}{c}\text { Inhibition Ratio } \\
\text { at } 100 \mu \mathrm{M} / \%\end{array}$ & $\mathrm{IC}_{50}(\mu \mathrm{M})$ \\
\hline DC-S357 & & & & 13 & \\
\hline DC-S358 & & & & 6 & \\
\hline DC-S359 & & & & 5 & \\
\hline DC-S360 & & & & 4 & \\
\hline DC-S361 & & & & -1 & \\
\hline DC-S362 & & & & -4 & \\
\hline DC-S363 & & & & -15 & \\
\hline DC-S364 & & & & 54 & 3.7 \\
\hline DC-S365 & & & & 10 & \\
\hline DC-S366 & & & & 9 & \\
\hline DC-S367 & & & & -1 & \\
\hline
\end{tabular}

\subsection{Selectivity of DC-S303}

A qualified lead compound or chemical probe should feature not only potent binding affinity, but also goodselectivity. Considering that besides SET7, there are some other methyltransferases that share the same cofactor and similar substrate pocket, we further tested the inhibition ratios of DC-S303 against other epigenetic targets, including SETD1B, SETD8, G9a, SMYD2 and EZH2 in vitro (Table 3). The results suggested that this compound displayed moderate selectivity against epigenetic targets that underscored its value for further optimization. 
Table 3. Selectivity of DC-S303 over other epigenetic targets.

\begin{tabular}{ccc}
\hline Compound No. & Target & Inhibition Ratio at $\mathbf{1 0 0} \boldsymbol{\mu \mathbf { M } / \mathbf { \% }}$ \\
\hline & SETD7 & 90.51 \\
& SETD1B & 27.12 \\
DC-S303 & SETD8 & 55.23 \\
& G9a & 52.56 \\
& SMYD2 & 24.55 \\
& EZH2 & 47.88 \\
\hline
\end{tabular}

\subsection{Binding Mode Prediction of DC-S303}

In order to predict the putative binding mode, a docking calculation was conducted as mentioned before. The proposed binding mode (Figure 6) suggests that it shares similar binding with the previous reported compound DC-S239 at the SAM binding region. It forms a key hydrogen bond with residue Lys294, which is reported to be a potential factor for selective SET7 inhibitor design. The linking benzene of the diphenyl group forms $\pi-\pi$ stacking interactions with Trp352, stabilizing its binding into the SAM pocket. The hydrogen bond between DC-S303 and SET7 contributes to the orientation by pulling the middle of this compound.

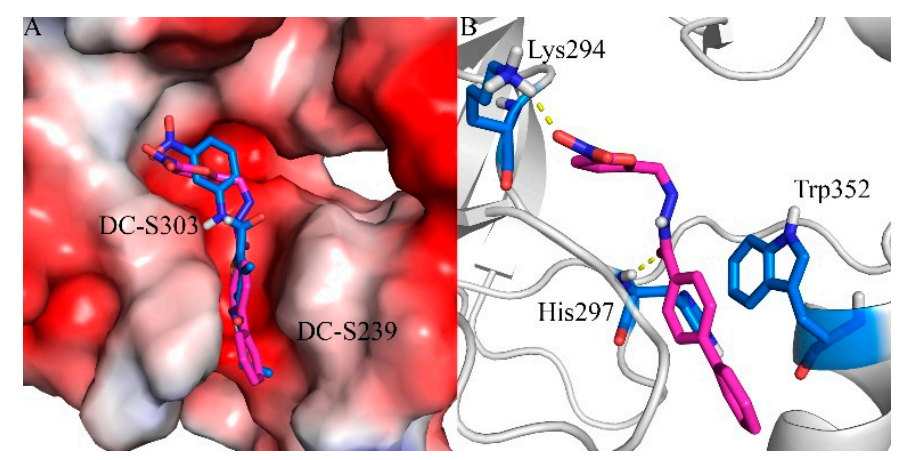

Figure 6. Predicted binding mode of DC-S303 against SET7. (A) Binding conformation alignment of DC-S303 and DC-S239. All the compounds are shown in sticks and the protein is shown in surface; (B) Putative binging mode of DC-S239 and important polar interactions. The compound is shown in magentas sticks and key residues are displayed in blue sticks.

\section{Materials and Methods}

\subsection{Virtual Screening: Ligand Database Preparation}

The Specs commercial database, containing approximately 200,000 molecules, was filtered using Pipeline Pilot, version 7.5 (Pipeline Pilot; Accelrys Software Inc., San Diego, CA, USA) based on Lipinski's Rule of Five [96] in order to get promising molecules with good drug-likeproperties. What's more, the 'pan-assay interference compounds' (PAINS) were also removed using the substructure filter protocol developed in our lab with Pipeline Pilot, version 7.5 [97-100]. As for those molecules for docking calculations, they were subjected to LigPrep to generate all stereoisomers and different protonation states with Epik [104].

\subsection{Virtual Screening: ProteinPreparation}

The protein structure was processed as previously described [92]. Twenty-nine X-ray crystal structures of SET7 are available in the PDB database, and the SET domain of these structures were aligned for comparison and root mean square deviation (RMSD) calculation, which is conserved in the SET domain-containing family. We obtained a maximum root mean-square derivation (RMSD) value of 0.37 , suggesting that the three-dimensional structure of the SET domain in SET7 is conserved. 
Considering the structure resolution and integrity, the crystal structure of SET7 complex with SAM (PDB ID: 1N6A) was chosen for docking. The protein was prepared with Protein Preparation Wizard Workflow, as provided in Maestro, with a $\mathrm{pH}$ value of $7.0 \pm 2.0$. Other parameters were set as the default.

\subsection{Virtual Screening: 2D Molecular FingerprintBased Similarity Search}

2D molecular fingerprint based similarity search was conducted with similarity search protocol implemented in Pipeline Pilot, version 7.5. Top-ranked 300 molecules were selected for further investigation. As for the SAR part of DC-S285, the similarity search is also performed as described in our previous published paper.

\subsection{Virtual Screening: Scaffold Hopping Based Similarity Search}

To get compounds with similar 3D conformations, scaffold hopping was performed with ChemMapper web server (http://lilab.ecust.edu.cn/chemmapper/) [93] against Specs molecule library. Other parameters were set as default.

\subsection{SET7 Inhibition Assays}

AlphaLISA assays were applied to determine the inhibitory activity targeting SET7. The purified SET7 protein was incubated in modified Tris buffer in 384-well plates (Perkin Elmer, Cat. No. 6007299, Waltham, MA, USA) at room temperature for $15 \mathrm{~min}$. The compounds were transferred to the assay plate using Echo in 100\% DMSO, and substrate solution was added to each well to start the reaction. Acceptor and donor beads were added and incubated for $60 \mathrm{~min}$ at room temperature, shielded from light. The endpoint was evaluated with EndSpire in Alpha mode. The experimental data was fitted in GraphPad Prism 5 to obtain inhibition values using the equation as follows:

$$
\text { Inhibition } \%=\frac{\text { Max }- \text { Siginal }}{\text { Max }- \text { Min }} \times 100 \%
$$

As for ${ }^{3}$ Hradioactive methylation assay, SAH was used as the reference compound and the compounds were tested in 10 concentrations in duplicate in modified Tris buffer ( $1 \times$ assay buffer). The following materials were purchased: SET7 (Enzo, Cat. No. ALX-201-178, New York, NY, USA), [ $\left.{ }^{3} \mathrm{H}\right]-S A M$ (PerkinElmer Inc., Lot. No. 1790854), SAH (Sigma, Cat. No. A9384-25MG, St. Louis, MO, USA) and 384-well Flashplate (Perkin Elmer, Cat. No. SMP410A001PK,). The compounds were transferred to the assay plate by Echo 550 with 3-fold dilution in 100\% DMSO where the final DMSO concentration is $1 \%$. Then the enzyme solution was transferred to the assay plate and $1 \times$ assay buffer was transferred for low control. After $15 \mathrm{~min}$ incubation at room temperature, peptide and [ $\left.{ }^{3} \mathrm{H}\right]-\mathrm{SAM}$ mix solution was transferred to each well to start the reaction. The cold SAM in $1 \times$ buffer was added to each well to stop the reaction after $60 \mathrm{~min}$ incubation at room temperature. $25 \mu \mathrm{L}$ of the whole reaction system per well was transferred to Flashplate which was washed with $\mathrm{dH}_{2} \mathrm{O}$ and $0.1 \%$ Tween-20 for three times after 60 min incubation. The data was read on Microbeta. All the inhibition assays are performed in duplicate.

\subsection{Enzymatic Selectivity Assays}

For SETD1B, G9a and SMYD2, the activities against those targets were tested in modified Tris buffer $(1 \times$ assay buffer). All the solid compounds were dissolved to $20 \mathrm{mM}$ in $100 \%$ DMSO. The materials used were SETD1B (Active Motif, Cat. No. M1083, Carlsbad, CA, USA), G9a (BPS, Cat. No. 51001, San Diego, CA, USA), SMYD2 (Active Motif, Cat. No. 31323, c), G9a (BPS, Cat. No. 51001,) and 384-well plate (Perkin Elmer, Cat. No. 6007299). Both the enzyme solution and the substrate solution were prepared in $1 \times$ assay buffer enzyme solution or $1 \times$ assay buffer for low control was transferred to the assay plate. Then substrate mix solution was added to each well to start the solution for 15 min incubation at room temperature. For SETD1B, G9a, the incubation time was adjusted to 
$60 \mathrm{~min}$ and for SMYD2, the incubation time was set to $240 \mathrm{~min}$. For detection, acceptor and donor beads were added and incubated for $60 \mathrm{~min}$ at room temperature, shielded from light. The endpoint was evaluated with EnSpire in Alpha mode.

The radioactive methylation inhibition assay of SETD8 was performed in modified Tris buffer. H3K27me peptide and $\left[{ }^{3} \mathrm{H}\right]-S A M$ (PerkinElmer, Cat No. NET1551MC) were added in $1 \mathrm{x}$ buffer as the substrate solution. The enzyme solution was incubated at room temperature for $15 \mathrm{~min}$ before substrate solution was added to each well to start the reaction. Cold SAM (Sigma, Cat. No. 7007-100MG) was added in $1 \mathrm{x}$ buffer to prepare the stop mix, and was added to stop the reaction; finally $10 \mu \mathrm{L}$ of the reaction system was transferred to flashplate (PerkinElmer Inc., Cat. No. SMP410A001PK) and incubated at room temperature for a minimum of $2 \mathrm{~h}$. The plate was washed three times with $\mathrm{dH}_{2} \mathrm{O}$ and $0.1 \%$ Tween-20, and the radioactivity signal was detected by liquid scintillation counting (MicroBeta, PerkinElmer). SAH was used as the reference compound.

The radioactive methylation inhibition assay of EZH2 was performed in modified Tris buffer. H3K27me peptide and $\left[{ }^{3} \mathrm{H}\right]-S A M$ (Perkin Elmer Inc. Waltham, MA, USA, Lot. No. 1731619) were added in $1 \mathrm{x}$ buffer as the substrate solution. The enz the yme solution was incubated at room temperature for $15 \mathrm{~min}$ before substrate solution was added to each well to start the reaction. Cold SAM (Sigma, Cat. NO. 7007) was added in $1 \times$ buffer to prepare stop mix (final concentration $0.5 \mathrm{mM}$ ), and was added to stop the reaction; finally $25 \mu \mathrm{L}$ of the reaction system was transferred to a FlashPlate (Perkin Elmer, Cat. No. SMP410A001PK) and incubated at room temperature for a minimum of $1 \mathrm{~h}$. The plate was washed three times with $\mathrm{dH}_{2} \mathrm{O}$ and $0.1 \%$ Tween-20, and the radioactivity was determined by liquid scintillation counting (MicroBeta). GSK-126 was used as the reference compound.

\subsection{NMR Experiment}

Ligand observed T1@ NMR experiment were applied to investigate ligand-protein interactions. All NMR spectra were acquired at $25^{\circ} \mathrm{C}$ on a $600 \mathrm{MHz}$ Bruker Avance III spectrometer equipped with a cryogenically cooled probe (Bruker Biospin, Ettlingen, Germany). Samples containing $20 \mu \mathrm{M}$ DC-S285, and $20 \mu \mathrm{M}$ DC-S285 in the presence of $2.5 \mu \mathrm{M}$ SET7 were dissolved in Tris- $\mathrm{HCl}$ buffer $(50 \mathrm{mM}$ Tris- $\mathrm{HCl}$, $100 \mathrm{mM} \mathrm{NaCl}, \mathrm{pH} 7.4,5 \% \mathrm{DMSO}, 95 \% \mathrm{D}_{2} \mathrm{O}$ ) and then used in NMR data acquisition. T1 $\varrho$ spectra were recorded by using the pulse sequence of solvent-suppressed ${ }^{1} \mathrm{D}^{1} \mathrm{H}$ CPMG (cpmgPr1d). The $90^{\circ}$ pulse length was adjusted to about $11.80 \mu \mathrm{s}$. A total of four dummy scans and 64 free induction decays (FIDs) were collected into $64 \mathrm{~K}$ acquisition points, covering a spectral width of $12 \mathrm{kHz}$ (20 ppm) and giving an acquisition time (ACQ) of $2.73 \mathrm{~s}$. STD data was acquired using 4 dummy scans and a relaxation delay of $3 \mathrm{~s}$, followed by a $40 \mathrm{~dB}$ pulsed irradiation at frequency of $-1.0 \mathrm{ppm}$ or $33 \mathrm{ppm}$ alternatively. The total acquisition time for STD spectrum was 23 min with 128 FIDs.

\subsection{Cell Culture and Cell Viability Assay}

MCF7, HL60, MV4-11, K562, Kasumi-1, U937, THP1, and Jurkat cell lines were purchased from American Type Culture Collection (Manassas, VA, USA). Fetal bovine serum was purchased from Life Technologies. MCF7 cells were cultured in DMEM medium supplemented with $10 \%$ fetal bovine serum at $37{ }^{\circ} \mathrm{C}$ in an incubator with 5\% $\mathrm{CO}_{2}$ atmosphere. HL60 and MV4-11 cells were cultured in 1640 medium supplemented with 10\% fetal bovine serum. K562, Kasumi-1 and HL60 were cultured in 96 plate at 10,000/well for $2 \mathrm{~h}$. DC-S285 was dissolved in DMSO (Sigma) and then stored at $4{ }^{\circ} \mathrm{C}$. The cells were incubated with DC-S285 at different concentrations ranging from 0 to $100 \mu \mathrm{M}$ for approximately $72 \mathrm{~h}$. The activities of DC-S239 against MCF7, HL60, MV4-11, K562, Kasumi-1, U937, THP1, and Jurkat were measured by the alamarBlue assays and MTT assays.

\section{Conclusions}

As a key member of the histone methyltransferase family, SET7 has been reported to play diverse biological roles, including cell proliferation, transcriptional network regulation in embryonic stem cell, cell cycle control, protein stability, heart morphogenesis and development. The dysfunction of 
SET7 is involved in the pathogenesis of several diseases including alopecia areata, breast cancer, tumor and cancer progression, atherosclerosis in human carotid plaques, chronic renal diseases, diabetes, obesity, ovarian cancer, prostate cancer, hepatocellular carcinoma, and pulmonary fibrosis. Despite its controversial role in multiple diseases, the aberrant expression patterns has been observed in the onset and progression of cancers. In peripheral blood mononuclear cells of patients, the histone modification patterns were altered and the expression of SET7 was elevated [69]. Emerging evidence has also demonstrated its role in solid tumors. Zhang et al. demonstrated that SET7 interacts with transcription factor GATA1 and promotes downstream VEGF transcription and tumor angiogenesis [40]. Inhibition of SET7 activity by the SET7 inhibitor cyproheptadine reduced the estrogen receptor alpha expression in MCF7 cells that is important for cancer progression, phencopying the SET7 knockdown studies [37].

Therefore, there is urgent need to develop novel SET7 inhibitors for further detailed chemical biology investigations as well as drug design for cancer therapy.

Several attempts have been made to develop SET7 inhibitors. Both (R)-PFI-2 and cyproheptadine were reported to bind with the peptide binding site while other inhibitors lack potencyor selectivity. Recently, we have reported the first cofactor-competitive SET7 inhibitor, DC-S239, with the help of structure-based drug design methods and chemical modifications. However, the chemotypes of current SET7 inhibitors are limited and no SET7 inhibitors have progressed into clinical trials. Thus, potent, selective SET7 inhibitors with novel scaffolds still need to be developed.

In this paper, the previous identified DC-S239 was used as the starting point for scaffold hopping and 2D fingerprint based similarity search leading to the identification of DC-S285, Both radioactive methylation assays and CPMG assays validate the binding between DC-S285 and SET7. In addition, in cellular studies, DC-S285 could significantly inhibit cancer cell proliferation in a dose-dependent manner with micromolar potencies.

Then in the second round similarity search based on DC-S285, the more potent compound DC-S303 was identified with an $\mathrm{IC}_{50}$ value of $1.1 \mu \mathrm{M}$. In vitro selectivity profiling demonstrated its moderate selectivity against other methyltransferases. Combined with molecular docking result, we carried out the SAR study that shed light on future medicinal chemistry optimizations. This promising compound will facilitate the SET7 related biology studies and provide a good scaffold for future drug design and development.

Acknowledgments: We are extremely grateful to National Centre for Protein Science Shanghai (Shanghai Science Research Center, Protein Expression and Purification system) for their instrument support and technical assistance. We gratefully acknowledge Xiaojie Lu, Jingqiu Liu, Shien Liu, Kongkai Zhu for their support and help. We gratefully acknowledge financial support from the Ministry of Science and Technology of China (National Key R\&D Program of China (2017YFB0202600 to H.D.)); the National Natural Science Foundation of China (21472208 and 81430084 to C.L.).

Author Contributions: Kai Xian Chen, Cheng Luo, Hong Ding and Fan Wang Meng conceived and designed the research; Fan Wang Meng performed the computational calculations; Hong Ding, Yu-Chih Liu, Chen Hua Zhang conducted the biological assays and the corresponding data analysis; Fu Lin Lian and Nai Xia Zhang were in charge of the NMR experiments; Cheng Luo, Hong Ding, Wen Chao Lu, Jun Chi Hu and Fan Wang Meng wrote the manuscript.

Conflicts of Interest: The authors declare no conflict of interest.

\section{References}

1. Tajima, K.; Yae, T.; Javaid, S.; Tam, O.; Comaills, V.; Morris, R.; Wittner, B.S.; Liu, M.Z.; Engstrom, A.; Takahashi, F.; et al. SETD1A modulates cell cycle progression through a miRNA network that regulates p53 target genes. Nat. Commun. 2015, 6, 8257. [CrossRef] [PubMed]

2. Chen, Y.H.; Hung, M.C.; Li, L.Y. EZH2: A pivotal regulator in controlling cell differentiation. Am. J. Transl. Res. 2012, 4, 364-375. [PubMed]

3. Martens, M.B.; Frega, M.; Classen, J.; Epping, L.; Bijvank, E.; Benevento, M.; van Bokhoven, H.; Tiesinga, P.; Schubert, D.; Nadif Kasri, N. Euchromatin histone methyltransferase 1 regulates cortical neuronal network development. Sci. Rep. 2016, 6, 35756. [CrossRef] [PubMed] 
4. Herz, H.M.; Garruss, A.; Shilatifard, A. SET for life: Biochemical activities and biological functions of SET domain-containing proteins. Trends Biochem. Sci. 2013, 38, 621-639. [CrossRef] [PubMed]

5. Greer, E.L.; Shi, Y. Histone methylation: A dynamic mark in health, disease and inheritance. Nat. Rev. Genet. 2012, 13, 343-357. [CrossRef] [PubMed]

6. Wagner, T.; Jung, M. New lysine methyltransferase drug targets in cancer. Nat. Biotechnol. 2012, 30, $622-623$. [CrossRef] [PubMed]

7. Arrowsmith, C.H.; Bountra, C.; Fish, P.V.; Lee, K.; Schapira, M. Epigenetic protein families: A new frontier for drug discovery. Nat. Rev. Drug Discov. 2012, 11, 384-400. [CrossRef] [PubMed]

8. Jones, P.A.; Issa, J.P.J.; Baylin, S. Targeting the cancer epigenome for therapy. Nat. Rev. Genet. 2016, 17, 630-641. [CrossRef] [PubMed]

9. Tough, D.F.; Tak, P.P.; Tarakhovsky, A.; Prinjha, R.K. Epigenetic drug discovery: Breaking through the immune barrier. Nat. Rev. Drug Discov. 2016, 15, 835-853. [CrossRef] [PubMed]

10. Nguyen, A.T.; Zhang, Y. The diverse functions of Dot1 and H3K79 methylation. Genes Dev. 2011, 25, 1345-1358. [CrossRef] [PubMed]

11. Keating, S.T.; El-Osta, A. Transcriptional regulation by the Set7 lysine methyltransferase. Epigenetics 2013, 8, 361-372. [CrossRef] [PubMed]

12. Wang, D.; Zhou, J.; Liu, X.; Lu, D.; Shen, C.; Du, Y.; Wei, F.Z.; Song, B.; Lu, X.; Yu, Y.; et al. Methylation of SUV39H1 by SET7/9 results in heterochromatin relaxation and genome instability. Proc. Natl. Acad. Sci. USA 2013, 110, 5516-5521. [CrossRef] [PubMed]

13. Carr, S.M.; Munro, S.; Kessler, B.; Oppermann, U.; La Thangue, N.B. Interplay between lysine methylation and Cdk phosphorylation in growth control by the retinoblastoma protein. Embo J. 2011, 30, 317-327. [CrossRef] [PubMed]

14. Munro, S.; Carr, S.M.; La Thangue, N.B. Diversity within the pRb pathway: Is there a code of conduct? Oncogene 2012, 31, 4343-4352. [CrossRef] [PubMed]

15. Yang, Z.; Zhang, Q.; Lu, Q.; Jia, Z.; Chen, P.; Ma, K.; Wang, W.; Zhou, C. ISL-1 promotes pancreatic islet cell proliferation by forming an ISL-1/Set7/9/PDX-1 complex. Cell Cycle 2015, 14, 3820-3829. [CrossRef] [PubMed]

16. Son, M.J.; Kim, W.K.; Oh, K.J.; Park, A.; Lee da, S.; Han, B.S.; Lee, S.C.; Bae, K.H. Methyltransferase and demethylase profiling studies during brown adipocyte differentiation. BMB Rep. 2016, 49, 388-393. [CrossRef] [PubMed]

17. Tuano, N.K.; Okabe, J.; Ziemann, M.; Cooper, M.E.; El-Osta, A. Set7 mediated interactions regulate transcriptional networks in embryonic stem cells. Nucleic Acids Res. 2016, 44, 9206-9217. [CrossRef] [PubMed]

18. Castano, J.; Morera, C.; Sese, B.; Boue, S.; Bonet-Costa, C.; Marti, M.; Roque, A.; Jordan, A.; Barrero, M.J. SETD7 Regulates the Differentiation of Human Embryonic Stem Cells. PLoS ONE 2016, 11, e0149502. [CrossRef] [PubMed]

19. Carr, S.M.; La Thangue, N.B. Cell cycle control by a methylation-phosphorylation switch. Cell Cycle 2011, 10, 733-734. [CrossRef] [PubMed]

20. Gaughan, L.; Stockley, J.; Wang, N.; McCracken, S.R.; Treumann, A.; Armstrong, K.; Shaheen, F.; Watt, K.; McEwan, I.J.; Wang, C.; et al. Regulation of the androgen receptor by SET9-mediated methylation. Nucleic Acids Res. 2011, 39, 1266-1279. [CrossRef] [PubMed]

21. Liu, Q.; Geng, H.; Xue, C.H.; Beer, T.M.; Qian, D.Z. Functional regulation of hypoxia inducible factor-1 alpha by SET9 lysine methyltransferase. Bba-Mol. Cell Res. 2015, 1853, 881-891.

22. Yang, J.; Huang, J.; Dasgupta, M.; Sears, N.; Miyagi, M.; Wang, B.; Chance, M.R.; Chen, X.; Du, Y.; Wang, Y.; et al. Reversible methylation of promoter-bound STAT3 by histone-modifying enzymes. Proc. Natl. Acad. Sci. USA 2010, 107, 21499-21504. [CrossRef] [PubMed]

23. Cho, H.S.; Suzuki, T.; Dohmae, N.; Hayami, S.; Unoki, M.; Yoshimatsu, M.; Toyokawa, G.; Takawa, M.; Chen, T.; Kurash, J.K.; et al. Demethylation of RB regulator MYPT1 by histone demethylase LSD1 promotes cell cycle progression in cancer cells. Cancer Res. 2011, 71, 655-660. [CrossRef] [PubMed]

24. Kim, J.D.; Kim, E.; Koun, S.; Ham, H.J.; Rhee, M.; Kim, M.J.; Huh, T.L. Proper Activity of Histone H3 Lysine 4 (H3K4) Methyltransferase Is Required for Morphogenesis during Zebrafish Cardiogenesis. Mol. Cells 2015, 38, 580-586. [CrossRef] [PubMed]

25. Muller, P.A.; Vousden, K.H. p53 mutations in cancer. Nat. Cell Biol. 2013, 15, 2-8. [CrossRef] [PubMed] 
26. Toledo, F.; Wahl, G.M. Regulating the p53 pathway: In vitro hypotheses, in vivo veritas. Nat. Rev. Cancer 2006, 6, 909-923. [CrossRef] [PubMed]

27. Wang, H.; Cao, R.; Xia, L.; Erdjument-Bromage, H.; Borchers, C.; Tempst, P.; Zhang, Y. Purification and functional characterization of a histone H3-lysine 4-specific methyltransferase. Mol. Cell 2001, 8, 1207-1217. [CrossRef]

28. Nishioka, K.; Chuikov, S.; Sarma, K.; Erdjument-Bromage, H.; Allis, C.D.; Tempst, P.; Reinberg, D. Set9, a novel histone $\mathrm{H} 3$ methyltransferase that facilitates transcription by precluding histone tail modifications required for heterochromatin formation. Gene Dev. 2002, 16, 479-489. [CrossRef] [PubMed]

29. Dhayalan, A.; Kudithipudi, S.; Rathert, P.; Jeltsch, A. Specificity analysis-based identification of new methylation targets of the SET7/9 protein lysine methyltransferase. Chem. Biol. 2011, 18, 111-120. [CrossRef] [PubMed]

30. Kassner, I.; Barandun, M.; Fey, M.; Rosenthal, F.; Hottiger, M.O. Crosstalk between SET7/9-dependent methylation and ARTD1-mediated ADP-ribosylation of histone H1.4. Epigenet. Chromatin 2013, 6, 1. [CrossRef] [PubMed]

31. Kassner, I.; Andersson, A.; Fey, M.; Tomas, M.; Ferrando-May, E.; Hottiger, M.O. SET7/9-dependent methylation of ARTD1 at K508 stimulates poly-ADP-ribose formation after oxidative stress. Open Biol. 2013, 3, 3. [CrossRef] [PubMed]

32. Oppenheimer, H.; Kumar, A.; Meir, H.; Schwartz, I.; Zini, A.; Haze, A.; Kandel, L.; Mattan, Y.; Liebergall, M.; Dvir-Ginzberg, M. Set7/9 Impacts COL2A1 Expression Through Binding and Repression of SirT1 Histone Deacetylation. J. Bone Miner. Res. 2014, 29, 348-360. [CrossRef] [PubMed]

33. Esteve, P.O.; Chin, H.G.; Benner, J.; Feehery, G.R.; Samaranayake, M.; Horwitz, G.A.; Jacobsen, S.E.; Pradhan, S. Regulation of DNMT1 stability through SET7-mediated lysine methylation in mammalian cells. Proc. Natl. Acad. Sci. USA 2009, 106, 5076-5081. [CrossRef] [PubMed]

34. Wang, J.; Hevi, S.; Kurash, J.K.; Lei, H.; Gay, F.; Bajko, J.; Su, H.; Sun, W.T.; Chang, H.; Xu, G.L.; et al. The lysine demethylase LSD1 (KDM1) is required for maintenance of global DNA methylation. Nat. Genet. 2009, 41, 125-129. [CrossRef] [PubMed]

35. Lezina, L.; Aksenova, V.; Ivanova, T.; Purmessur, N.; Antonov, A.V.; Tentler, D.; Fedorova, O.; Garabadgiu, A.V.; Talianidis, I.; Melino, G.; et al. KMTase Set7/9 is a critical regulator of E2F1 activity upon genotoxic stress. Cell Death Differ. 2014, 21, 1889-1899. [CrossRef] [PubMed]

36. Kontaki, H.; Talianidis, I. Lysine methylation regulates E2F1-induced cell death. Mol. Cell 2010, 39, 152-160. [CrossRef] [PubMed]

37. Subramanian, K.; Jia, D.; Kapoor-Vazirani, P.; Powell, D.R.; Collins, R.E.; Sharma, D.; Peng, J.M.; Cheng, X.D.; Vertino, P.M. Regulation of estrogen receptor alpha by the SET7 lysine methyltransferase. Mol. Cell 2008, 30, 336-347. [CrossRef] [PubMed]

38. Calnan, D.R.; Webb, A.E.; White, J.L.; Stowe, T.R.; Goswami, T.; Shi, X.; Espejo, A.; Bedford, M.T.; Gozani, O.; Gygi, S.P.; et al. Methylation by Set9 modulates FoxO3 stability and transcriptional activity. Aging (Albany NY) 2012, 4, 462-479. [CrossRef] [PubMed]

39. Balasubramaniyan, N.; Ananthanarayanan, M.; Suchy, F.J. Direct methylation of FXR by Set7/9, a lysine methyltransferase, regulates the expression of FXR target genes. Am. J. Physiol. Gastrointest. Liver Physiol. 2012, 302, G937-G947. [CrossRef] [PubMed]

40. Zhang, Y.; Liu, J.; Lin, J.; Zhou, L.; Song, Y.; Wei, B.; Luo, X.; Chen, Z.; Chen, Y.; Xiong, J.; et al. The transcription factor GATA1 and the histone methyltransferase SET7 interact to promote VEGF-mediated angiogenesis and tumor growth and predict clinical outcome of breast cancer. Oncotarget 2016, 7, 9859-9875. [CrossRef] [PubMed]

41. Fu, L.; Wu, H.; Cheng, S.Y.; Gao, D.; Zhang, L.; Zhao, Y. Set7 mediated Gli3 methylation plays a positive role in the activation of Sonic Hedgehog pathway in mammals. eLife 2016, 5, e15690. [CrossRef] [PubMed]

42. Liu, X.; Chen, Z.; Xu, C.; Leng, X.; Cao, H.; Ouyang, G.; Xiao, W. Repression of hypoxia-inducible factor alpha signaling by Set7-mediated methylation. Nucleic Acids Res. 2015, 43, 5081-5098. [CrossRef] [PubMed]

43. Baek, S.H.; Kim, K.I. Regulation of HIF-1 alpha stability by lysine methylation. BMB Rep. 2016, 49, $245-246$. [CrossRef] [PubMed]

44. Shan, Z.; Han, Q.; Nie, J.; Cao, X.; Chen, Z.; Yin, S.; Gao, Y.; Lin, F.; Zhou, X.; Xu, K.; et al. Negative regulation of interferon-induced transmembrane protein 3 by SET7-mediated lysine monomethylation. J. Biol. Chem. 2013, 288, 35093-35103. [CrossRef] [PubMed] 
45. Han, P.; Gao, D.; Zhang, W.; Liu, S.; Yang, S.; Li, X. Puerarin suppresses high glucose-induced MCP-1 expression via modulating histone methylation in cultured endothelial cells. Life Sci. 2015, 130, 103-107. [CrossRef] [PubMed]

46. Li, X.; Li, C.; Li, X.; Cui, P.; Li, Q.; Guo, Q.; Han, H.; Liu, S.; Sun, G. Involvement of Histone Lysine Methylation in p21 Gene Expression in Rat Kidney In Vivo and Rat Mesangial Cells In Vitro under Diabetic Conditions. J. Diabetes Res. 2016, 2016, 3853242. [CrossRef] [PubMed]

47. Brasacchio, D.; Okabe, J.; Tikellis, C.; Balcerczyk, A.; George, P.; Baker, E.K.; Calkin, A.C.; Brownlee, M.; Cooper, M.E.; El-Osta, A. Hyperglycemia Induces a Dynamic Cooperativity of Histone Methylase and Demethylase Enzymes Associated with Gene-Activating Epigenetic Marks That Coexist on the Lysine Tail. Diabetes 2009, 58, 1229-1236. [CrossRef] [PubMed]

48. Ea, C.K.; Baltimore, D. Regulation of NF-kappa B activity through lysine monomethylation of p65. Proc. Natl. Acad. Sci. USA 2009, 106, 18972-18977. [CrossRef] [PubMed]

49. Masatsugu, T.; Yamamoto, K. Multiple lysine methylation of PCAF by Set9 methyltransferase. Biochem Biophys. Res. Commun. 2009, 381, 22-26. [CrossRef] [PubMed]

50. Spaeth, J.M.; Walker, E.M.; Stein, R. Impact of Pdx1-associated chromatin modifiers on islet beta-cells. Diabetes Obes. Metab. 2016, 18 (Suppl. 1), 123-127. [CrossRef] [PubMed]

51. Wang, W.; Shi, Q.; Guo, T.; Yang, Z.; Jia, Z.; Chen, P.; Zhou, C. PDX1 and ISL1 differentially coordinate with epigenetic modifications to regulate insulin gene expression in varied glucose concentrations. Mol. Cell. Endocrinol. 2016, 428, 38-48. [CrossRef] [PubMed]

52. Maganti, A.V.; Maier, B.; Tersey, S.A.; Sampley, M.L.; Mosley, A.L.; Ozcan, S.; Pachaiyappan, B.; Woster, P.M.; Hunter, C.S.; Stein, R.; et al. Transcriptional Activity of the Islet beta Cell Factor Pdx1 Is Augmented by Lysine Methylation Catalyzed by the Methyltransferase Set7/9. J. Biol. Chem. 2015, 290, 9812-9822. [CrossRef] [PubMed]

53. Aguilo, F.; Li, S.D.; Balasubramaniyan, N.; Sancho, A.; Benko, S.; Zhang, F.; Vashisht, A.; Rengasamy, M.; Andino, B.; Chen, C.H.; et al. Deposition of 5-Methylcytosine on Enhancer RNAs Enables the Coactivator Function of PGC-1 alpha. Cell Rep. 2016, 14, 479-492. [CrossRef] [PubMed]

54. Huq, M.D.; Tsai, N.P.; Khan, S.A.; Wei, L.N. Lysine trimethylation of retinoic acid receptor-alpha: A novel means to regulate receptor function. Mol. Cell. Proteom. 2007, 6, 677-688. [CrossRef] [PubMed]

55. Zhao, L.; Zhang, Y.; Gao, Y.; Geng, P.; Lu, Y.; Liu, X.; Yao, R.; Hou, P.; Liu, D.; Lu, J.; et al. JMJD3 promotes SAHF formation in senescent WI38 cells by triggering an interplay between demethylation and phosphorylation of RB protein. Cell Death Differ. 2015, 22, 1630-1640. [CrossRef] [PubMed]

56. He, S.Y.; Owen, D.R.; Jelinsky, S.A.; Lin, L.L. Lysine Methyltransferase SETD7 (SET7/9) Regulates ROS Signaling through mitochondria and NFE2L2/ARE pathway. Sci. Rep.-UK 2015, 5, 14368. [CrossRef] [PubMed]

57. Elkouris, M.; Kontaki, H.; Stavropoulos, A.; Antonoglou, A.; Nikolaou, K.C.; Samiotaki, M.; Szantai, E.; Saviolaki, D.; Brown, P.J.; Sideras, P.; et al. SET9-Mediated Regulation of TGF-beta Signaling Links Protein Methylation to Pulmonary Fibrosis. Cell Rep. 2016, 15, 2733-2744. [CrossRef] [PubMed]

58. Vasileva, E.; Fedorova, O.; Shuvalov, O.; Daks, A.; Petukhov, A.; Barlev, N. The role of methyltransferase Set7/9 interaction with RNA-binding protein Sam68. Int. J. Mol. Med. 2015, 36, S46.

59. Liu, X.Y.; Wang, D.L.; Zhao, Y.; Tu, B.; Zheng, Z.X.; Wang, L.N.; Wang, H.Y.; Gu, W.; Roeder, R.G.; Zhu, W.G. Methyltransferase Set7/9 regulates p53 activity by interacting with Sirtuin 1 (SIRT1). Proc. Natl. Acad. Sci. USA 2011, 108, 1925-1930. [CrossRef] [PubMed]

60. Albacker, C.E.; Storer, N.Y.; Langdon, E.M.; DiBiase, A.; Zhou, Y.; Langenau, D.M.; Zon, L.I. The Histone Methyltransferase SUV39H1 Suppresses Embryonal Rhabdomyosarcoma Formation in Zebrafish. PLoS ONE 2013, 8. [CrossRef] [PubMed]

61. Couture, J.F.; Collazo, E.; Hauk, G.; Trievel, R.C. Structural basis for the methylation site specificity of SET7/9. Nat. Struct. Mol. Biol. 2006, 13, 140-146. [CrossRef] [PubMed]

62. Kouskouti, A.; Scheer, E.; Staub, A.; Tora, L.; Talianidis, I. Gene-specific modulation of TAF10 function by SET9-mediated methylation. Mol. Cell 2004, 14, 175-182. [CrossRef]

63. Pagans, S.; Kauder, S.E.; Kaehlcke, K.; Sakane, N.; Schroeder, S.; Dormeyer, W.; Trievel, R.C.; Verdin, E.; Schnolzer, M.; Ott, M. The Cellular Lysine Methyltransferase Set7/9-KMT7 Binds HIV-1 TAR RNA, Monomethylates the Viral Transactivator Tat, and Enhances HIV Transcription. Cell Host Microbe 2010, 7, 234-244. [CrossRef] [PubMed] 
64. Guo, Q.Y.; Li, X.X.; Han, H.B.; Li, C.Y.; Liu, S.J.; Gao, W.H.; Sun, G.D. Histone Lysine Methylation in TGF-beta 1 Mediated p21 Gene Expression in Rat Mesangial Cells. Biomed. Res. Int. 2016, 2016, 6927234. [CrossRef] [PubMed]

65. Sasaki, K.; Doi, S.; Nakashima, A.; Irifuku, T.; Yamada, K.; Kokoroishi, K.; Ueno, T.; Doi, T.; Hida, E.; Arihiro, K.; et al. Inhibition of SET Domain-Containing Lysine Methyltransferase 7/9 Ameliorates Renal Fibrosis. J. Am. Soc. Nephrol. 2016, 27, 203-215. [CrossRef] [PubMed]

66. Gupta, N.; Madapura, M.P.; Bhat, U.A.; Rao, M.R.S. Mapping of Post-translational Modifications of Transition Proteins, TP1 and TP2, and Identification of Protein Arginine Methyltransferase 4 and Lysine Methyltransferase 7 as Methyltransferase for TP2. J. Biol. Chem. 2015, 290, 12101-12122. [CrossRef] [PubMed]

67. Oudhoff, M.J.; Braam, M.J.S.; Freeman, S.A.; Wong, D.; Rattray, D.G.; Wang, J.; Antignano, F.; Snyder, K.; Refaeli, I.; Hughes, M.R.; et al. SETD7 Controls Intestinal Regeneration and Tumorigenesis by Regulating Wnt/beta-Catenin and Hippo/YAP Signaling. Dev. Cell 2016, 37, 47-57. [CrossRef] [PubMed]

68. Zhang, W.J.; Wu, X.N.; Shi, T.T.; Xu, H.T.; Yi, J.; Shen, H.F.; Huang, M.F.; Shu, X.Y.; Wang, F.F.; Peng, B.L.; et al. Regulation of Transcription Factor Yin Yang 1 by SET7/9-mediated Lysine Methylation. Sci. Rep.-UK 2016, 6, 21718. [CrossRef] [PubMed]

69. Zhao, M.; Liang, G.; Wu, X.; Wang, S.; Zhang, P.; Su, Y.; Yin, H.; Tan, Y.; Zhang, J.; Lu, Q. Abnormal epigenetic modifications in peripheral blood mononuclear cells from patients with alopecia areata. Br. J. Dermatol. 2012, 166, 266-273. [CrossRef] [PubMed]

70. Song, Y.C.; Zhang, J.L.; Tian, T.; Fu, X.; Wang, W.J.; Li, S.N.; Shi, T.T.; Suo, A.L.; Ruan, Z.P.; Guo, H.; et al. SET7/9 inhibits oncogenic activities through regulation of Gli-1 expression in breast cancer. Tumor Biol. 2016, 37, 9311-9322. [CrossRef] [PubMed]

71. Chen, Y.Y.; Yang, S.S.; Hu, J.W.; Yu, C.Q.; He, M.X.; Cai, Z.L. Increased Expression of SETD7 Promotes Cell Proliferation by Regulating Cell Cycle and Indicates Poor Prognosis in Hepatocellular Carcinoma. PLoS ONE 2016, 11. [CrossRef] [PubMed]

72. Adachi, Y.; Takeuchi, T.; Nagayama, T.; Furihata, M. T-Cadherin Modulates Tumor-Associated Molecules in Gallbladder Cancer Cells. Cancer Investig. 2010, 28, 120-126. [CrossRef] [PubMed]

73. Akiyama, Y.; Koda, Y.; Byeon, S.J.; Shimada, S.; Nishikawaji, T.; Sakamoto, A.; Chen, Y.X.; Kojima, K.; Kawano, T.; Eishi, Y.; et al. Reduced expression of SET7/9, a histone mono-methyltransferase, is associated with gastric cancer progression. Oncotarget 2016, 7, 3966-3983. [CrossRef] [PubMed]

74. Kim, Y.; Nam, H.J.; Lee, J.; Park, D.Y.; Kim, C.; Yu, Y.S.; Kim, D.; Park, S.W.; Bhin, J.; Hwang, D.; et al. Methylation-dependent regulation of HIF-1 alpha stability restricts retinal and tumour angiogenesis. Nat. Commun. 2016, 7, 10347. [CrossRef] [PubMed]

75. Lezina, L.; Aksenova, V.; Fedorova, O.; Malikova, D.; Shuvalov, O.; Antonov, A.V.; Tentler, D.; Garabadgiu, A.V.; Melino, G.; Barlev, N.A. KMT Set7/9 affects genotoxic stress response via the Mdm2 axis. Oncotarget 2015, 6, 25843-25855. [CrossRef] [PubMed]

76. Shen, C.C.; Wang, D.L.; Liu, X.Y.; Gu, B.; Du, Y.P.; Wei, F.Z.; Cao, L.L.; Song, B.Y.; Lu, X.P.; Yang, Q.Y.; et al. SET7/9 regulates cancer cell proliferation by influencing beta-catenin stability. Faseb J. 2015, 29, 4313-4323. [CrossRef] [PubMed]

77. Greissel, A.; Culmes, M.; Burgkart, R.; Zimmermann, A.; Eckstein, H.H.; Zernecke, A.; Pelisek, J. Histone acetylation and methylation significantly change with severity of atherosclerosis in human carotid plaques. Cardiovasc. Pathol. 2016, 25, 79-86. [CrossRef] [PubMed]

78. Yuan, H.; Reddy, M.A.; Deshpande, S.; Jia, Y.; Park, J.T.; Lanting, L.L.; Jin, W.; Kato, M.; Xu, Z.G.; Das, S.; et al. Epigenetic Histone Modifications Involved in Profibrotic Gene Regulation by 12/15-Lipoxygenase and Its Oxidized Lipid Products in Diabetic Nephropathy. Antioxid. Redox. Signal. 2016, 24, 361-375. [CrossRef] [PubMed]

79. Paneni, F.; Costantino, S.; Battista, R.; Castello, L.; Capretti, G.; Chiandotto, S.; Scavone, G.; Villano, A.; Pitocco, D.; Lanza, G.; Volpe, M.; et al. Adverse epigenetic signatures by histone methyltransferase Set7 contribute to vascular dysfunction in patients with type 2 diabetes mellitus. Circ. Cardiovasc. Genet. 2015, 8 , 150-158. [CrossRef] [PubMed]

80. Okabe, J.; Orlowski, C.; Balcerczyk, A.; Tikellis, C.; Thomas, M.C.; Cooper, M.E.; El-Osta, A. Distinguishing Hyperglycemic Changes by Set7 in Vascular Endothelial Cells. Circ. Res. 2012, 110, 1067-1121. [CrossRef] [PubMed] 
81. Goru, S.K.; Kadakol, A.; Pandey, A.; Malek, V.; Sharma, N.; Gaikwad, A.B. Histone H2AK119 and H2BK120 mono-ubiquitination modulate SET7/9 and SUV39H1 in type 1 diabetes-induced renal fibrosis. Biochem. J. 2016, 473, 3937-3949. [CrossRef] [PubMed]

82. Costantino, S.; Paneni, F.; Virdis, A.; Volpe, M.; Taddei, S.; Cosentino, F. Chromatin changes by methyltransferase Set7 induce inflammatory adhesion molecules and endothelial dysfunction in small visceral arteries from insulin resistant subjects. Eur. Heart J. 2015, 36, 112-113.

83. Ciccarelli, M.; Vastolo, V.; Albano, L.; Lecce, M.; Cabaro, S.; Liotti, A.; Longo, M.; Oriente, F.; Russo, G.L.; Macchia, P.E.; et al. Glucose-induced expression of the homeotic transcription factor Prep1 is associated with histone post-translational modifications in skeletal muscle. Diabetologia 2016, 59, 176-186. [CrossRef] [PubMed]

84. Al-Haddad, R.; Karnib, N.; Assaad, R.A.; Bilen, Y.; Emmanuel, N.; Ghanem, A.; Younes, J.; Zibara, V.; Stephan, J.S.; Sleiman, S.F. Epigenetic changes in diabetes. Neurosci. Lett. 2016, 625, 64-69. [CrossRef] [PubMed]

85. Son, M.J.; Kim, W.K.; Park, A.; Oh, K.J.; Kim, J.H.; Han, B.S.; Kim, I.C.; Chi, S.W.; Park, S.G.; Lee, S.C.; et al. Set7/9, a methyltransferase, regulates the thermogenic program during brown adipocyte differentiation through the modulation of p53 acetylation. Mol. Cell. Endocrinol. 2016, 431, 46-53. [CrossRef] [PubMed]

86. Zhou, J.; Xie, M.; Shi, Y.; Luo, B.H.; Gong, G.H.; Li, J.N.; Wang, J.P.; Zhao, W.J.; Zi, Y.; Wu, X.Y.; et al. MicroRNA-153 functions as a tumor suppressor by targeting SET7 and ZEB2 in ovarian cancer cells. Oncol. Rep. 2015, 34, 111-120. [CrossRef] [PubMed]

87. D'Adamo, C.R.; D’Urso, A.; Ryan, K.A.; Yerges-Armstrong, L.M.; Semba, R.D.; Steinle, N.I.; Mitchell, B.D.; Shuldiner, A.R.; McArdle, P.F. A Common Variant in the SETD7 Gene Predicts Serum Lycopene Concentrations. Nutrients 2016, 8, 82. [CrossRef] [PubMed]

88. Han, T.; Wan, Y.S.; Wang, J.; Zhao, P.; Yuan, Y.; Wang, L.; She, Y.L.; Broering, R.; Lu, M.J.; Ye, L.B.; et al. Set7 Facilitates Hepatitis C Virus Replication via Enzymatic Activity-Dependent Attenuation of the IFN-Related Pathway. J. Immunol. 2015, 194, 2757-2768. [CrossRef] [PubMed]

89. Ali, I.; Ramage, H.; Boehm, D.; Dirk, L.M.A.; Sakane, N.; Hanada, K.; Pagans, S.; Kaehlcke, K.; Aull, K.; Weinberger, L.; et al. The HIV-1 Tat Protein Is Monomethylated at Lysine 71 by the Lysine Methyltransferase KMT7. J. Biol. Chem. 2016, 291, 16240-16248. [CrossRef] [PubMed]

90. Hsu, C.H.; Peng, K.L.; Jhang, H.C.; Lin, C.H.; Wu, S.Y.; Chiang, C.M.; Lee, S.C.; Yu, W.C.Y.; Juan, L.J. The HPV E6 oncoprotein targets histone methyltransferases for modulating specific gene transcription. Oncogene 2012, 31, 2335-2349. [CrossRef] [PubMed]

91. Barsyte-Lovejoy, D.; Li, F.L.; Oudhoff, M.J.; Tatlock, J.H.; Dong, A.P.; Zeng, H.; Wu, H.; Freeman, S.A.; Schapira, M.; Senisterra, G.A.; et al. (R)-PFI-2 is a potent and selective inhibitor of SETD7 methyltransferase activity in cells. Proc. Natl. Acad. Sci. USA 2014, 111, 12853-12858. [CrossRef] [PubMed]

92. Meng, F.W.; Cheng, S.F.; Ding, H.; Liu, S.; Liu, Y.; Zhu, K.K.; Chen, S.J.; Lu, J.Y.; Xie, Y.Q.; Li, L.J.; et al. Selective Histone Methyltransferase SET7 Inhibitors by Pharmacophore- and Docking-Based Virtual Screening. J. Med. Chem. 2015, 58, 8166-8181. [CrossRef] [PubMed]

93. Gong, J.Y.; Cai, C.Q.; Liu, X.F.; Ku, X.; Jiang, H.L.; Gao, D.Q.; Li, H.L. ChemMapper: A versatile web server for exploring pharmacology and chemical structure association based on molecular 3D similarity method. Bioinformatics 2013, 29, 1827-1829. [CrossRef] [PubMed]

94. Gleeson, M.P.; Hersey, A.; Montanari, D.; Overington, J. Probing the links between in vitro potency, ADMET and physicochemical parameters. Nat. Rev. Drug Discov. 2011, 10, 197-208. [CrossRef] [PubMed]

95. Van de Waterbeemd, H.; Gifford, E. ADMET in silico modelling: Towards prediction paradise? Nat. Rev. Drug Discov. 2003, 2, 192-204. [PubMed]

96. Lipinski, C.A.; Lombardo, F.; Dominy, B.W.; Feeney, P.J. Experimental and computational approaches to estimate solubility and permeability in drug discovery and development settings. Adv. Drug Deliv. Rev. 2001, 46, 3-26. [CrossRef]

97. Baell, J.B.; Holloway, G.A. New Substructure Filters for Removal of Pan Assay Interference Compounds (PAINS) from Screening Libraries and for Their Exclusion in Bioassays. J. Med. Chem. 2010, 53, 2719-2740. [CrossRef] [PubMed]

98. Whitty, A. Growing PAINS in academic drug discovery. Future Med. Chem. 2011, 3, 797-801. [CrossRef] [PubMed] 
99. Baell, J.; Walters, M.A. Chemical con artists foil drug discovery. Nature 2014, 513, 481-483. [CrossRef] [PubMed]

100. Baell, J.B. Observations on screening-based research and some concerning trends in the literature. Future Med. Chem. 2010, 2, 1529-1546. [CrossRef] [PubMed]

101. Friesner, R.A.; Banks, J.L.; Murphy, R.B.; Halgren, T.A.; Klicic, J.J.; Mainz, D.T.; Repasky, M.P.; Knoll, E.H.; Shelley, M.; Perry, J.K.; et al. Glide: A new approach for rapid, accurate docking and scoring. 1. Method and assessment of docking accuracy. J. Med. Chem. 2004, 47, 1739-1749. [CrossRef] [PubMed]

102. Friesner, R.A.; Murphy, R.B.; Repasky, M.P.; Frye, L.L.; Greenwood, J.R.; Halgren, T.A.; Sanschagrin, P.C.; Mainz, D.T. Extra precision glide: Docking and scoring incorporating a model of hydrophobic enclosure for protein-ligand complexes. J. Med. Chem. 2006, 49, 6177-6196. [CrossRef] [PubMed]

103. Halgren, T.A.; Murphy, R.B.; Friesner, R.A.; Beard, H.S.; Frye, L.L.; Pollard, W.T.; Banks, J.L. Glide: A new approach for rapid, accurate docking and scoring. 2. Enrichment factors in database screening. J. Med. Chem. 2004, 47, 1750-1759. [CrossRef] [PubMed]

104. Shelley, J.C.; Cholleti, A.; Frye, L.L.; Greenwood, J.R.; Timlin, M.R.; Uchimaya, M. Epik: A software program for $\mathrm{pK}$ (a) prediction and protonation state generation for drug-like molecules. J. Comput. Aided Mol. Des. 2007, 21, 681-691. [CrossRef] [PubMed]

Sample Availability: Samples of the compounds are not available from the authors. 